\title{
Osteolipoma of the Oral Cavity: A Case Report
}

\author{
Márcio Bruno Figueiredo Amaral • Caio Ferreira Borges • \\ João Batista de Freitas · Hermínia Marques Capistrano • \\ Ricardo Alves Mesquita
}

Received: 27 March 2012/ Accepted: 28 May 2012/Published online: 1 August 2012

(C) Association of Oral and Maxillofacial Surgeons of India 2012

\begin{abstract}
Background Osteolipoma located in the oral cavity and pharyngeal region is rare.

Case Report The current case presents the clinical-ultrasonographic-radiographic-histopathological features of the diagnosis and management of osteolipoma of the mandibular buccal mucosa.

Discussion A literature review of the osteolipoma of the oral cavity and pharyngeal region is also presented. In this localization study, 14 well-documented cases could be found in English-language literature, in which the mean age of patients was 50.6 years, and slight predilection for male gender could be identified. The majority of cases appeared in the oral cavity $(67 \%)$. The data demonstrated
\end{abstract}

\author{
M. B. F. Amaral $(\bowtie)$ C C. F. Borges · J. B. de Freitas \\ Department of Oral and Maxillofacial Surgery, School of \\ Dentistry, Pontifícia Universidade Católica de Minas Gerais, Av. \\ Dom José Gaspar, 500-Coração Eucarístico, Belo Horizonte, \\ MG 30535-901, Brazil \\ e-mail: marciobrunoamaral@yahoo.com.br \\ C. F. Borges \\ e-mail: efoa_caio@hotmail.com \\ J. B. de Freitas \\ e-mail: zanfre@terra.com.br
}

M. B. F. Amaral · J. B. de Freitas · R. A. Mesquita Department of Oral Surgery and Pathology, School of Dentistry, Universidade Federal de Minas Gerais, Av. Antônio Carlos, 6627-Pampulha, Belo Horizonte, MG 31270-901, Brazil e-mail: ramesquita@odonto.ufmg.br

H. M. Capistrano

Department of Oral Pathology, School of Dentistry, Pontifícia Universidade Católica de Minas Gerais, Av. Dom José Gaspar, 500-Coração Eucarístico, Belo Horizonte, MG 30535-901, Brazil

e-mail: herminialau@uol.com.br that osteolipoma of the oral cavity and pharyngeal region is an asymptomatic ( $80 \%)$ lesion without bone attachment $(80 \%)$. The size of the lesions ranged from 8 to $90 \mathrm{~mm}$ in diameter (mean $=36 \mathrm{~mm}$ ), with an evolution time ranging from 1 to 35 years (mean $=7.7$ years). Similar to the present case, no recurrence could be identified in works which reported on the follow-up period.

Keywords Lipoma - Osteolipoma - Oral cavity · Pharyngeal

\section{Background}

Lipoma is a common mesenchymal benign neoplasm which can affect any part of the human body and occurs in the head and neck region in approximately $20 \%$ of the cases [1]. However, lipomas in the oral cavity and pharyngeal region represent 1 to $4 \%$ of all benign oral lesions [2]. Osteolipoma is a rare histopathological variant of the lipoma, which is observed in many anatomic sites, including the scapula, vertebral spine, neck, skull, suprasellar region, tuber cinereum, oral cavity, and pharyngeal region $[1,3]$.

There are 14 well-documented cases of osteolipoma of the oral cavity and pharyngeal region (OLOP) reported in English-language literature. The present study aims to describe a new case of osteolipoma of the buccal mucosa in a 51-year-old man, together with clinical, imaging, histologi$\mathrm{cal}$, and treatment features. In addition, a literature review of OLOP cases in English-language literature is also presented.

\section{Case Report}

A 51-year-old man with non-contributory medical, social, and cultural records was referred to the Oral and 

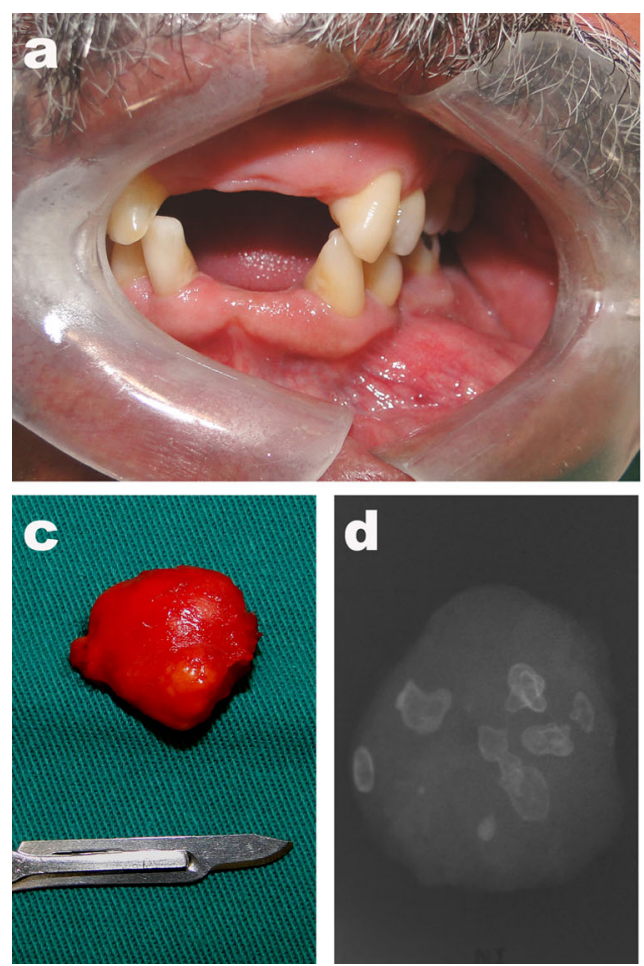

Fig. 1 Clinical and imaging features of patient with osteolipoma of the oral cavity. a Swelling of left mandibular buccal mucosa coated by a normal color and texture of the mucosa; b ultrasonography demonstrates a well-defined hyperechogenic mass with areas of calcification (red head arrows); c surgical specimen size

Maxillofacial Surgery Services, Department of Dentistry, Pontifícia Universidade Católica de Minas Gerais in Belo Horizonte, Brazil, to evaluate a nodule in his mouth. The patient reported that the lesion had been present for 3 years, with slow progressive growth. Through clinical examination, a swelling with slight asymmetry in the left mandibular cheek area could be observed extraorally. No cervical lymph nodes were palpable. Intraorally, a swelling of the left mandibular buccal mucosa, close to teeth 33 and 34 , could be observed. The lesion presented a well-defined, movable, but firm consistency, coated by a normal color and texture of mucosa, measuring $20 \times 15 \mathrm{~mm}$, which was painless and uneventful (Fig. 1a). The ultrasonography of the left buccal region showed a hyperechoic appearance of the lesion with areas of calcification (Fig. 1b). Lipoma and a benign minor salivary gland tumor were proposed as differential clinical diagnosis. An excisional biopsy was performed, through which it was possible to observe a soft red mass with yellowish areas (Fig. 1c). A radiography with periapical film of the surgical specimen showed irregular and radiopaque structures (Fig. 1d). The histopathology demonstrated a fibrous capsule involving a proliferation of the mature fat cells, containing a thin septa of fibrous conjunctive tissue associated with the trabecula of the vital lamellar bone and the compact bone
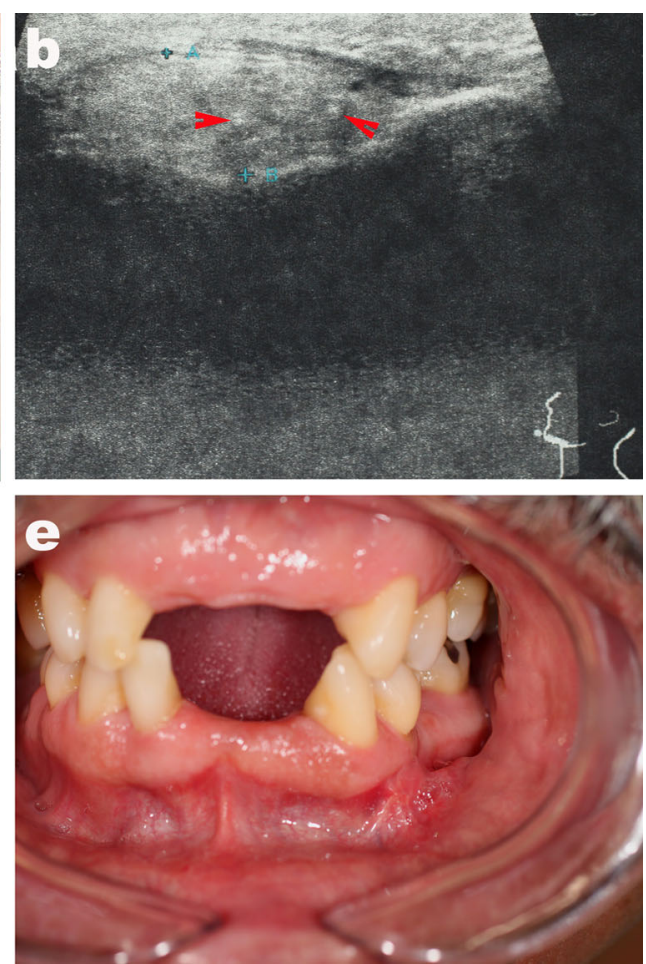

$20 \times 15 \mathrm{~mm}$, with red color and yellowish areas; $\mathbf{d}$ radiographic image of the surgical specimen showing radiopaque structures within the lesion; e clinical aspects of patient after one year of follow-up, with no evidence of recurrence. (Color figure online)

(Fig. 2a-d). The diagnosis of osteolipoma was therefore established. The postoperative period proved to be uneventful. The patient is currently undergoing routine follow-up with no signs of recurrence after 12 months (Fig. 1e).

\section{Discussion}

Previous case reports of OLOP, published from 1961 to 2011, were researched within the English-language literature from PUBMED, inserting the following keywords: osteolipoma, ossifying lipoma, osseous lipoma, and metaplasia. All cases using clinical-histopathological diagnoses were included in this review [1-14]. Together with the current case report, a total of 15 cases, which were deemed acceptable for evaluation and analysis and were selected. The data from all cases are presented in Table 1.

The current case presents clinical-ultrasonographicradiographic-histopathological features of the diagnosis and management of osteolipoma of the mandibular buccal mucosa. Fourteen cases of OLOP could be found in the literature, but only in individual case reports. The mean age of patients with OLOP was 50.6 years, ranging from 6 to 81 years of age. Slight predilection for male $(53 \%)$ gender could be identified, and the ratio of male to female patients 


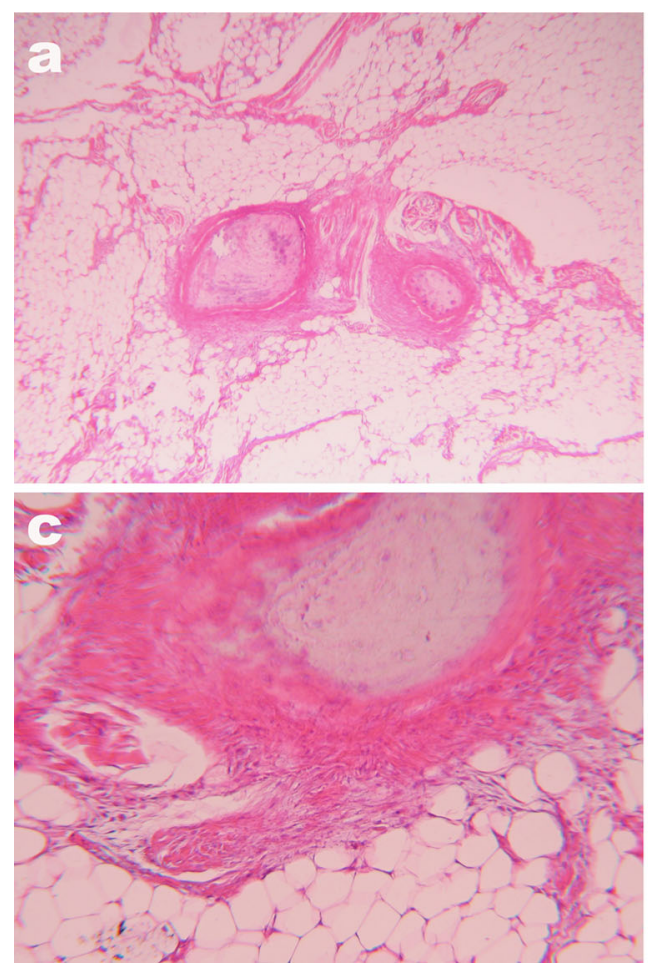

Fig. 2 Histopathological features of the osteolipoma. a Proliferation of the mature fat cells with septa of the fibrous conjunctive tissue and central area of calcified tissue (haematoxylin and eosin stain, $\times 100$ original magnification). Calcified tissue represented by lamellar

was 1.1:1. The majority of cases of OLOP could be found in the oral cavity $(67 \%)$. Only $5(33 \%)$ cases occurred in the pharyngeal region. The data demonstrated that OLOP is an asymptomatic $(80 \%)$ lesion without bone attachment $(80 \%)$. The size of the lesions ranged from 8 to $90 \mathrm{~mm}$ in diameter (mean $=36 \mathrm{~mm})$, with an evolution time ranging from 1 to 35 years (mean $=7.7$ years). Similar to the present case, no recurrence could be identified in works which reported on follow-up periods.

Symptomatic osteolipoma could only be found in the pharyngeal region $[9,12,14]$. This may well be explained by the fact that these lesions are located in invisible areas which allow for the growth of the tumor, which can in turn lead to the compression of adjacent structures. Bone attachment in OLOP was described by Godby et al. [4], Durmaz et al. [12], and Adebiyi et al. [3], but this is an infrequent description in the oral cavity and pharyngeal region $(20 \%)$.

Many lesions have been reported as differential clinical diagnoses of the osteolipoma due to several anatomic places where this lesion can be found [2]. However, ultrasonography, computed tomography, and magnetic resonance imaging can aid in the differential diagnosis of the osteolipoma, when the identification of the radiopaque structures within the lesion is possible $[9,15]$. In the current case, the radiopaque structures were observed in the

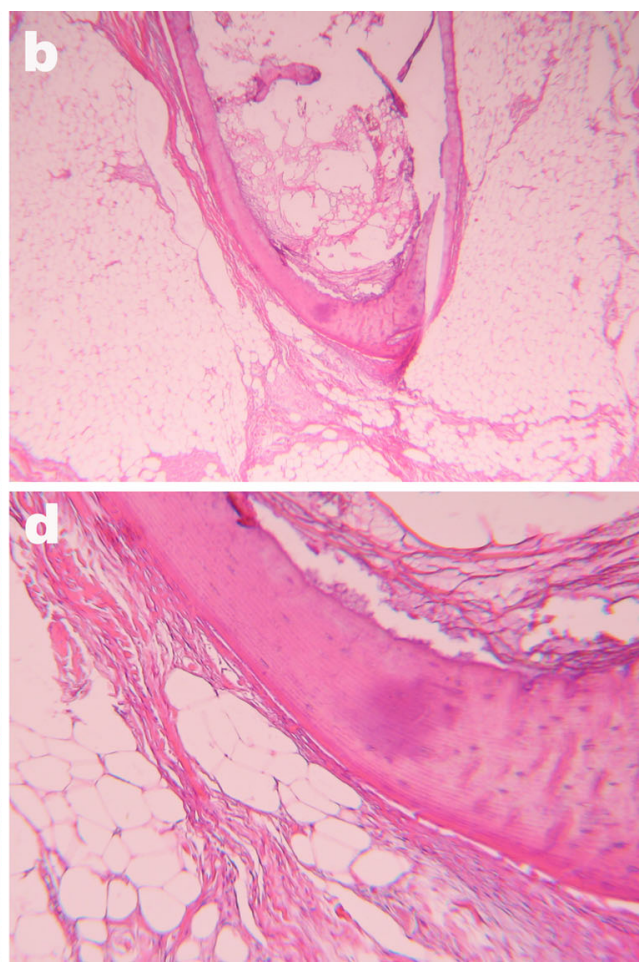

(c, d haematoxylin and eosin stain, $\times 200$ and $\times 400$ original magnification, respectively) and compact bone (b haematoxylin and eosin, $\times 400$ original magnification), both in association with mature fat cells

ultrasonography of the lesion and in the radiography of the surgical specimen.

Other histopathological variants of lipoma have also been described: (1) fibrolipoma, (2) chondrolipoma, (3) intramuscular lipoma, (4) angiolipoma, (5) angiomyolipoma, (6) myolipoma, (7) myelolipoma, (8) chondroid lipoma, (9) spindle cell lipoma, (10) pleomorphic lipoma, and (11) sialolipoma [16]. Osteolipoma is characterized by the scattering of the lamellar bone trabeculae among proliferating mature fat cells [2, 7]. Several theories have been proposed to explain the bone formation in lipoma. The origin of the osteolipoma from fat cells transformation into neoplastic tissue and in bone, would be the result of the metaplasia of fibroblasts in osteoblasts seems to be more acceptable $[1,10,11]$. Scattered bone trabeculae associated with mature fat cells could be observed in the present case, thus indicating the diagnosis of osteolipoma.

The management of OLOP includes a complete surgical excision of the lesion and demonstrates a low risk of recurrence, as in the other variants of lipoma. In the 14 cases of OLOP reported in the literature, no recurrence was described $[1,11,17,18]$. In accordance with the literature, the present case was easily completed excised, with no recurrence in the follow-up period.

In summary, OLOP is a rare variant of lipoma which occurs more frequently in patients in the sixth decade of 
Table 1 Clinical profile of osteolipoma of the oral cavity and pharyngeal region

\begin{tabular}{|c|c|c|c|c|c|c|c|c|}
\hline Authors & $\begin{array}{l}\text { Age } \\
\text { (years) }\end{array}$ & Gender & Site & $\begin{array}{l}\text { Size (large } \\
\text { diameter) } \\
(\mathrm{mm})\end{array}$ & Clinical presentation & $\begin{array}{l}\text { Bone } \\
\text { attachment }\end{array}$ & $\begin{array}{l}\text { Time of } \\
\text { evolution } \\
\text { (years) }\end{array}$ & Follow-up \\
\hline $\begin{array}{l}\text { Godby } \\
\text { et al. } \\
{[4]}\end{array}$ & 54 & M & Sublingual & 70 & Painless, soft, fluctuant & Yes & 1 & NA \\
\hline $\begin{array}{l}\text { Hughes } \\
\text { [5] }\end{array}$ & 69 & M & $\begin{array}{l}\text { Right mandibular } \\
\text { buccal vestibule }\end{array}$ & 35 & $\begin{array}{l}\text { Slight facial asymmetry, } \\
\text { soft, nontender }\end{array}$ & No & NA & NA \\
\hline $\begin{array}{l}\text { Dutescu } \\
\text { et al. } \\
{[6]}\end{array}$ & 40 & M & $\begin{array}{l}\text { Left submandibular } \\
\text { space }\end{array}$ & 70 & $\begin{array}{l}\text { Facial asymmetry, } \\
\text { peripherally tender, } \\
\text { almost pasty, firm in } \\
\text { center }\end{array}$ & No & 3 & NA \\
\hline $\begin{array}{l}\text { Allard } \\
\text { et al. } \\
\text { [7] }\end{array}$ & 81 & $\mathrm{~F}$ & $\begin{array}{l}\text { Left mandibular buccal } \\
\text { vestibule }\end{array}$ & 35 & $\begin{array}{l}\text { Facial asymmetry, } \\
\text { painless, bony } \\
\text { consistency }\end{array}$ & No & 35 & NA \\
\hline $\begin{array}{l}\text { Ohno } \\
\text { et al. } \\
{[8]}\end{array}$ & 58 & $\mathrm{~F}$ & $\begin{array}{l}\text { Extending from right } \\
\text { parapharyngeal gap to } \\
\text { the medial side of the } \\
\text { mandible }\end{array}$ & 90 & $\begin{array}{l}\text { Soft and immovable } \\
\text { mass displacing the } \\
\text { submandibular gland } \\
\text { inferiorly }\end{array}$ & No & 1 & $\begin{array}{l}\text { No } \\
\text { recurrence }\end{array}$ \\
\hline $\begin{array}{l}\text { Piattelli } \\
\text { et al. } \\
\text { [10] }\end{array}$ & 49 & $\mathrm{~F}$ & $\begin{array}{l}\text { Left lateral border of the } \\
\text { tongue }\end{array}$ & 8 & $\begin{array}{l}\text { Oval, well- } \\
\text { circumscribed, hard, } \\
\text { and nontender }\end{array}$ & No & 8 & $\begin{array}{l}\text { No } \\
\text { recurrence }\end{array}$ \\
\hline $\begin{array}{l}\text { Minutoli } \\
\text { et al. } \\
\text { [9] }\end{array}$ & 46 & $\mathrm{~F}$ & $\begin{array}{l}\text { Right parapharyngeal } \\
\text { space }\end{array}$ & 40 & $\begin{array}{l}\text { Oval shaped mass } \\
\text { causing dysphagia and } \\
\text { paresthesia }\end{array}$ & No & NA & NA \\
\hline $\begin{array}{l}\text { Castilho } \\
\text { et al. } \\
\text { [11] }\end{array}$ & 65 & $\mathrm{~F}$ & Left buccal mucosa & 10 & $\begin{array}{l}\text { Nodular, well-defined, } \\
\text { soft, painless, and } \\
\text { yellowish }\end{array}$ & No & NA & $\begin{array}{l}\text { No } \\
\text { recurrence }\end{array}$ \\
\hline $\begin{array}{l}\text { Durmaz } \\
\text { et al. } \\
\text { [12] }\end{array}$ & 21 & M & $\begin{array}{l}\text { Extending from } \\
\text { posterior surface of } \\
\text { the nasal septum to } \\
\text { superior and posterior } \\
\text { wall of the } \\
\text { nasopharynx }\end{array}$ & 26 & $\begin{array}{l}\text { Well-defined and firm } \\
\text { on palpation, mild } \\
\text { hearing loss }\end{array}$ & Yes & 5 & $\begin{array}{l}\text { No } \\
\text { recurrence }\end{array}$ \\
\hline $\begin{array}{l}\text { Saghafi } \\
\text { et al. } \\
\text { [2] }\end{array}$ & 68 & M & $\begin{array}{l}\text { Right mandibular } \\
\text { alveolar mucosa }\end{array}$ & 18 & $\begin{array}{l}\text { Firm, movable mass } \\
\text { covered by smooth } \\
\text { normal oral mucosa }\end{array}$ & No & 4 & $\begin{array}{l}\text { No } \\
\text { recurrence }\end{array}$ \\
\hline $\begin{array}{l}\text { Gokul } \\
\text { et al. } \\
\text { [13] }\end{array}$ & 6 & M & $\begin{array}{l}\text { Between hard palatal } \\
\text { shelves }\end{array}$ & 30 & $\begin{array}{l}\text { Painless, soft swelling, } \\
\text { normal overlying } \\
\text { mucosa }\end{array}$ & No & NA & NA \\
\hline $\begin{array}{l}\text { de Castro } \\
\text { et al. } \\
{[1]}\end{array}$ & 47 & $\mathrm{~F}$ & Left buccal mucosa & 15 & $\begin{array}{l}\text { Nodular, well- } \\
\text { circumscribed, } \\
\text { mobile, painless, } \\
\text { yellowish }\end{array}$ & No & NA & $\begin{array}{l}\text { No } \\
\text { recurrence }\end{array}$ \\
\hline $\begin{array}{l}\text { Bulkeley } \\
\text { et al. } \\
\text { [14] }\end{array}$ & 68 & M & $\begin{array}{l}\text { Left parapharyngeal } \\
\text { space }\end{array}$ & 40 & $\begin{array}{l}\text { Left jaw pain, numbness } \\
\text { in the mandibular and } \\
\text { maxillary branch of } \\
\text { the trigeminal nerve }\end{array}$ & No & NA & NA \\
\hline $\begin{array}{l}\text { Adebiyi } \\
\text { et al. } \\
{[3]}\end{array}$ & 37 & $\mathrm{~F}$ & Left hard palate & 40 & $\begin{array}{l}\text { Oval, nontender, } \\
\text { covered by normal } \\
\text { mucosa }\end{array}$ & Yes & 10 & NA \\
\hline $\begin{array}{l}\text { Current } \\
\text { study }\end{array}$ & 51 & M & $\begin{array}{l}\text { Left mandibular buccal } \\
\text { mucosa }\end{array}$ & 20 & $\begin{array}{l}\text { Nodular, well-defined, } \\
\text { asymptomatic, } \\
\text { movable firm mass } \\
\text { covered by normal } \\
\text { mucosa }\end{array}$ & No & 3 & $\begin{array}{l}\text { No } \\
\text { recurrence }\end{array}$ \\
\hline
\end{tabular}


Table 1 continued

\begin{tabular}{|c|c|c|c|c|c|c|c|c|}
\hline Authors & $\begin{array}{l}\text { Age } \\
\text { (years) }\end{array}$ & Gender & Site & $\begin{array}{l}\text { Size (large } \\
\text { diameter) } \\
(\mathrm{mm})\end{array}$ & Clinical presentation & $\begin{array}{l}\text { Bone } \\
\text { attachment }\end{array}$ & $\begin{array}{l}\text { Time of } \\
\text { evolution } \\
\text { (years) }\end{array}$ & Follow-up \\
\hline \multirow[t]{2}{*}{ Total } & $\begin{array}{r}\text { Mean: } \\
50.6\end{array}$ & $\begin{array}{l}53 \% \mathrm{M} \\
47 \% \mathrm{~F}\end{array}$ & Oral cavity: $67 \%$ & $\begin{array}{l}\text { Mean: } \\
36 \mathrm{~mm}\end{array}$ & Asymptomatic: $80 \%$ & No: $80 \%$ & Mean: 7,7 & \multirow[t]{2}{*}{$\begin{array}{l}\text { No } \\
\text { recurrence }\end{array}$} \\
\hline & $\begin{array}{r}\text { Range: } \\
6-81\end{array}$ & Ratio: $1.1: 1$ & $\begin{array}{l}\text { Pharyngeal region: } \\
33 \%\end{array}$ & $\begin{array}{l}\text { Range: } \\
8-90 \mathrm{~mm}\end{array}$ & Symptomatic: $20 \%$ & Yes: $20 \%$ & $\begin{array}{r}\text { Range: } \\
1-35\end{array}$ & \\
\hline
\end{tabular}

$N A$ not available, $M$ male, $F$ female

life, presenting slight predilection for male gender. It is more common in the oral cavity, without bone attachment and slow growth. Recurrence is not expected; however, it is important to remember that new case reports regarding OLOP are warranted in an attempt to better define conclusions regarding its nature and biological behavior.

Acknowlegments The authors would like to thank the Conselho Nacional de Desenvolvimento Científico e Tecnológico (CNPq, \#309209/2010-2, \#472045/2011-3). RA Mesquita is research fellow of CNPq.

Conflict of interest None.

\section{References}

1. de Castro AL, de Castro EV, Felipini RC, Ribeiro AC, Soubhia AM (2010) Osteolipoma of the buccal mucosa. Med Oral Patol Oral Cir Bucal 15:e347-e349

2. Saghafi S, Mellati E, Sohrabi M, Raahpeyma A, Salehinejad J, Zare-Mahmoodabadi R (2008) Osteolipoma of the oral and pharyngeal region: report of a case and review of the literature. Oral Surg Oral Med Oral Pathol Oral Radiol Endod 105:e30-e34

3. Adebiyi KE, Ugboko VI, Maaji SM, Ndubuizu G (2011) Osteolipoma of the palate: report of a case and review of the literature. Niger J Clin Pract 14:242-244. doi:10.4103/1119-3077

4. Godby AF, Drez PB, Field JL (1961) Sublingual lipoma with ectopic bone formation: report of a case. Oral Surg Oral Med Oral Pathol 14:625-629

5. Hughes CL (1966) Intraoral lipoma with osseous metaplasia. Oral Surg Oral Med Oral Pathol 21:576-578

6. Dutescu N, Georgesco L, Hary M (1973) Lipoma of the submandibular space with osseous metaplasia: report of a case. Oral Surg 35:611-615
7. Allard RHB, Block P, Van der Kwast WAM, Van der Waal I (1982) Oral lipomas with osseous and chondrous metaplasia: report of two cases. J Oral Pathol 11:18-25

8. Ohno Y, Muraoka M, Ohashi Y, Nakai Y, Wakasa K (1998) Osteolipoma in the parapharyngeal space. Eur Arch Otorhinolaryngol 255:15-317

9. Minutoli F, Mazziotti S, Gaeta M, Vinci S, Mastroeni M, Blandino A (2001) Ossifying lipoma of the parapharyngeal space: cT and MRI findings. Eur Radiol 11:1818-1821

10. Piatelli A, Fioroni M, Iezzi G, Rubini C (2001) Osteolipoma of the tongue. Oral Oncol 37:468-470

11. Castilho RM, Squarize CH, Nunes FD, Pinto DS Jr (2004) Osteolipoma: a rare lesion in the oral cavity. Br J Oral Maxillofac Surg 42:363-364

12. Durmaz A, Tosun F, Kurt B, Gerek M, Birkent H (2007) Osteolipoma of the nasopharynx. J Craniofac Surg 18:1176-1179

13. Gokul S, Ranjini KV, Kirankumar K, Hallikeri K (2009) Congenital osteolipoma associated with cleft palate: a case report. Int J Oral Maxillofac Surg 38:91-97. doi:10.1016/j.ijom.2008.09.005

14. Bulkeley W, Mills OL, Gonzalvo A, Wong K (2010) Osteolipoma of the parapharyngeal space mimicking liposarcoma: a case report. Head Neck 34:301-303

15. Zhong LP, Zhao SF, Chen GF, Ping FY (2004) Ultrasonographic appearance of lipoma in the oral and maxillofacial region. Oral Surg Oral Med Oral Pathol Oral Radiol Endod 98:738-740

16. Juliasse LE, Nonaka CF, Pinto LP, RdeA Freitas, Miguel MC (2010) Lipomas of the oral cavity: clinical and histopathological study of 41 cases in a Brazilian population. Eur Arch Otorhinolaryngol 267:459-465

17. Fregnani ER, Pires FR, Falzoni R, Lopes MA, Vargas PA (2003) Lipomas of the oral cavity: clinical findings, histological classification and proliferative activity of 46 cases. Int J Oral Maxillofac Surg 32:49-53

18. Furlong MA, Fanburg-Smith JC, Childers ELB (2004) Lipoma of the oral and maxillofacial region: site and subclassification of 125 cases. Oral Surg Oral Med Oral Pathol Oral Radiol Endod 98:441-450 